Akreditasi Ristekdikti,

No: 30/E/KPT/2019 (Sinta 4)

Paradigma,

DOI: https://doi.org/10.31294/p.v23i2.11395

Vol. 23, No. 2, September 2021

P-ISSN 1410-5063, E-ISSN: 2579-3500

\title{
Penerapan Metode Data Mining C4.5 Untuk Pemilihan Penerima Kartu Indonesia Pintar (KIP)
}

\author{
Muhamad Yunus ${ }^{1}$, Hanandriya Ramadhan², Dimas Rizki Aji , Agus Yulianto ${ }^{4}$ \\ ${ }^{1}$ Program Studi Sistem Informasi, Universitas Nusa Mandiri Jakarta \\ e-mail: ${ }^{1}$ muhamadyunus908@gmail.com, ${ }^{2}$ dimasrizkiaji@ gmail.com, ${ }^{3}$ hanandriyaramadhan@ gmail.com, \\ ${ }^{4}$ agus.aag@nusamandiri.ac.id
}

\begin{abstract}
Abstraksi - Pendidikan di Indonesia selalu berkonflik dengan masalah kemiskinan dan prestasi siswa dievaluasi setiap akhir semester untuk mengetahui hasil belajar yang telah dicapai. Bantuan KIP (Kartu Indonesia Pintar) dapat berupa uang sekolah, bantuan belajar siswa dan penghargaan bagi siswa yang berprestasi atau bagi siswa yang kurang mampu. Maka penelitian ini untuk memudahkan sekolah SMPN 38 Jakarta dalam menyeleksi dan juga lebih tepat sasaran guna mengoptimalkan sekolah untuk lebih menyeleksi calon KIP (Kartu Indonesia Pintar), dengan ini mampu meringankan tanggungan orang tua dalam biaya sekolah dan juga meningkatkan keinginan belajar siswa. Metode penelitian yang digunakan adalah metode klasifikasi Decision Tree data mining dengan algoritma C4.5. Berdasarkan hasil uji coba dan pembahasan yang telah dilakukan untuk pemilihan penerima Kartu Indonesia Pintar (KIP) dapat diselesaikan. Data siswa yang diperoleh dari SMPN 35 Jakarta dapat diprediksi dengan akurasi yang cukup tinggi, hasil ini diperoleh dengan akurasi mencapai 90,24\% dengan errorate 9,75\% sehingga dengan hasil tersebut algoritma C4.5 sangat baik dalam menentukan pemilihan penerima Kartu Indonesia Pintar (KIP).
\end{abstract}

Kata Kunci : KIP (Kartu Indonesia Pintar), Data Mining, Klasifikasi, Decision Tree, C4.5.

Abstracts - Education in Indonesia is always in conflict with the problem of poverty and student achievement is evaluated at the end of each semester to determine the learning outcomes that have been achieved. KIP (Smart Indonesia Card) assistance can be in the form of tuition fees, student study assistance and awards for students who excel or for students who are less fortunate. So this research is to make it easier for SMPN 35 Jakarta schools in selecting and also being more targeted in order to optimize schools to better select KIP (Indonesia Cardcandidates Smart), with this it is able to ease the burden of parents in school fees and also increase students' desire to learn. The research method used is theclassification method Decision Tree data mining with the C4.5 algorithm. Based on the results of trials and discussions that have been carried out, the selection of KIP recipients (Kartu Indonesia Pintar) can be completed. Student data obtained from SMPN 35 Jakarta can be predicted with accuracy, high the results obtained with the accuracy of $90.24 \%$ with errorate $9,75 \%$ so with these results the C4.5 algorithm is very good in determining the selection of KIP (Smart Indonesia Card).

Keywords : KIP (Indonesia Cardcandidates Smart), Data Mining, Classification, Decision Tree, C4.5.

\section{PENDAHULUAN}

Pendidikan di Indonesia selalu bertentangan dengan masalah kemiskinan dan prestasi anak didik dievaluasi setiap akhir semester untuk mendeteksi hasil belajar yang sudah dicapai. Kemiskinan ini nanti menjadi alasan seorang mengajukan permintaan KIP (Kartu Indonesia Pintar) untuk lembaga pendidikan. Berbagai upaya telah dilakukan, antara lain pemberian dana bantuan sekolah melalui program Surat Keterangan Tidak Mampu (SKTM) yang dikeluarkan oleh kecamatan setempat. Agar penerima KIP ini terus terpacu meningkatkan prestasi akademisnya, tidak salah apabila lembaga pendidikan tidak serta merta menyetujui permintaan KIP yang diajukan (Pauziah, 2016).
SMPN 38 Jakarta merupakan sekolah menengah pertama yang beralamat di Jl. Karet Pasar Baru Barat I No.2, RT.2/RW.6, Karet Tengsin, Kecamatan Tanah Abang, Kota Jakarta Pusat, Daerah Khusus Ibukota Jakarta 10220. Sekolah adalah suatu lembaga penyelenggara pendidikan bagi siswa (Ardiansyah, 2018). Banyak fasilitas - fasilitas yang kita dapatkan di sekolah seperti KIP (Kartu Indonesia Pintar) merupakan program pengembangan agar siswa terus dapat melanjutkan studi nya, bantuan KIP (Kartu Indonesia Pintar) dapat berupa biaya pendidikan, bantuan belajar siwa dan suatu penghargaan untuk siswa yang berprestasi atau untuk siswa yang kurang mampu dengan adanya penerapan metode data mining untuk menyeleksi pemilihan penerima KIP (Kartu Indonesia Pintar) dapat mempermudah mendapatkan kriteria calon penerima. Dalam

http://ejournal.bsi.ac.id/ejurnal/index.php/paradigma/issue/archive/ 191 
penelitian ini permasalahan yang dihadapi untuk mendapatkan KIP (Kartu Indonesia Pintar) ada beberapa kriteria - kriteria yang sudah di tetapkan pada program studi ini seperti mata pelajaran, penghasilan orang tua, tanggungan orang tua, dan lain - lain. oleh sebab itu tidak semua yang mendaftarkan diri sebagai calon penerima KIP (Kartu Indonesia Pintar) dapat di terima, hanya yang memenuhi kriteria dan syarat tersebut yang dapat menerima KIP (Kartu Indonesia Pintar), maka perlu adanya penerapan metode data mining dengan algoritma C4.5 untuk membantu menyeleksi pemilihan siapa yang berhak menerima KIP (Kartu Indonesia Pintar) tersebut. Data mining adalah serangkaian proses untuk menggali nilai tambahan berupa informasi yang selama ini tidak diketahui secara manual dari suatu basis data. Algoritma C4.5 menurut (Vulandari, 2017) merupakan salah satu metode yang banyak di gunakan untuk menghasilkan decision tree (Adinungroho, 2018). Algoritma yang dapat digunakan pada penelitian disini yaitu algoritma C4.5 untuk mempermudah menyeleksi pemilihan penerima KIP (Kartu Indonesia Pintar) di SMPN 38 Jakarta dengan tingkat akurasi yang tinggi. Dengan jumlah peserta yang mengajukan KIP (Kartu Indonesia Pintar) banyak serta indikator kriteria yang banyak, maka dibutuhkanlah suatu sistem yang dapat membantu untuk menentukan siapa yang berhak untuk mendapatkan KIP (Kartu Indonesia Pintar) dari SMPN 38 Jakarta.

\section{METODOLOGI PENELITIAN}

Metode penelitian merupakan suatu faktor yang sangat penting untuk memecahkan suatu masalah dan turut menuntukan keberhasilan suatu penelitian. Metode penelitian pada dasarnya merupakan cara ilmiah untuk mendapatkan data dengan tujuan dan kegunaan tertentu (Prof.Dr.Sugiono, 2017). Penelitian yang peneliti gunakan peneliti ambil sesuai dengan judul yang merupakan metode klasifikasi Decision Tree data mining dengan algoritma C4.5, klasifikasi Decision Tree merupakan suatu metode pengelompokan atau classification data yang sangat mudah dimengerti (Prasetyowati, 2017). Ada banyak metode data mining yang digunakan untuk tujuan yang berbeda. Metode klasifikasi digunakan untuk membantu memahami pengelompokan data. Pada penelitian ini peneliti juga menggunakan metode algoritma C4.5, Algoritma C4.5 merupakan salah satu algoritma yang secara luas digunakan, khususnya di area machine learning yang memiliki beberapa perbaikan dari algoritma sebelumnya yaitu ID3. Algoritma C4.5 dan ID3 merupakan model yang tak terpisahkan, karena membangun sebuah pohon keputusan, dibutuhkan algoritma C4.5. Menjelaskan kronologis penelitian, termasuk desain penelitian, prosedur penelitian (dalam bentuk algoritma, Pseudocode atau lainnya), bagaimana untuk menguji dan akuisisi data. Deskripsi dari program penelitian harus didukung referensi, sehingga penjelasan tersebut dapat diterima secara ilmiah.

\section{Data Mining}

Data mining merupakan langkah analisis terhadap proses pengetahuan didalam basis knowledge discovery in database (KDD). KDD berhubungan dengan intergrasi dengan penemuan ilmiah, Interpretasi dan visualisasi dari pola-pola sejumlah data (Dr. Suyanto, 2017). Data mining menurut (Vulandari, 2017) adalah serangakain proses untuk menggali nilai tambahan berupa informasi yang selama ini tidak diketaui secara manual dari suatu basis data. Berdasarkan dari sejumlah pengertian diatas, meyakini pandangan peneliti data mining adalah suatu tempat untuk mengolah data yang jumlahnya cukup banyak bahkan sampai ribuan untuk di olah dengan metode-metode serta adanya perhitungan data dan penyusunan data secara spesifik, kemudian membentuk sebuah informasi.

\section{Algoritma $\mathrm{C} 4.5$}

Algoritma C4.5 adalah algoritma yang digunakan untuk membentuk pohon keputusan, yang merupakan metode klasifikasi dan prediksi yang sangat kuat dan terkenal. metode pohon keputusan mengubah fakta yang sangat besar menjadi pohon keputusan yang merepresentasikan aturanaturan dapat dengan mudah dimengerti dalam bahasa alami. (Sugiyarti, n.d.).

Dengan pejelasan di atas algoritma C4.5 kita gunakan untuk mempermudah peneliti memprediksi sebuah nilai menjadi informasi, dan menurut peneliti algoritma C4.5 merupakan perngembangan dari ID3 dengan membentuk pohon keputusan untuk memprediksi atau memperkirakan sebuah kejadian mendapatkan informasi.

Hasil dari algoritma C4.5 adalah pohon keputusan, sehingga mudah untuk dipahami dan dipahami proses penggunaan algoritma ini untuk menyelesaikan kasus adalah sebagai berikut (Azahari, 2021):

\section{1) Mencari nilai Gain}

$\operatorname{Gain}(S, A)=$ Entropy $(S)-\sum_{i=1}^{n}-\frac{\left|S_{i}\right|}{s} *$
Entropy $(S) \ldots \ldots(1)$

Dimana keterangan dari rumus tersebut adalah:

$\mathrm{S} \quad=$ Himpunan Kasus

$\mathrm{A} \quad=$ atribut

$\mathrm{n} \quad=$ jumlah partisi

pi $\quad=$ porsi dari si kepada $\mathrm{s}$

$|s i| \quad=$ jumlah kasus pada nilai atribut/kriteria

$|s| \quad=$ jumlah kasus atau total kasus 
2) Mencari nilai Entropy

$$
\operatorname{Entropy}(S)=\sum_{i=1}^{n}-p i * \log 2 p i \ldots \ldots(2)
$$

Keterangan:

$\mathrm{S}$ : Himpunan Kasus

N: Jumlah Partisi S

Pi: Proporsi dari Si terhadap S.

\section{Decision Tree}

Decision tree dalam (Prasetyowati, 2017) adalah suatu metode pengelompokan atau classification data yang sangat mudah dimengerti. Dalam perkembangan decision tree dijadikan sebagai acuan penalaran untuk mempermudah memahami dari permasalahan yang dihadapi. Metode ini sangat membantu untuk menggambarkan aturan yang dapat dengan mudah dipahami dengan bahasa alami dan juga dapat diekpresikan dalam bentuk bahasa basis data seperti Structured Query Language untuk mencari record pada kategori tertentu.

Decision tree menurut peneliti merupakan metode pengelompokan atau klasifikasi untuk mempermudah model klasifikasi yang tidak relevan dan mudah dimengerti. Salah satu metode decision tree yang peneliti ambil yaitu $\mathrm{C} 4.5$ yang termasuk dari bagian metode decision tree terpopuler.

Dalam referensi (Prasetyowati, 2017) Pohon Keputusan adalah pohon yang digunakan sebagai prosedur penalaran untuk mendapatkan jawaban dari masalah yang dimasukkan. Pohon yang dibentuk tidak selalu berupa pohon biner. Jika semua fitur dalam data set menggunakan 2 macam nilai kategorikal maka bentuk pohon yang didapatkan berupa pohon biner. Jika dalam fitur berisi lebih dari 2 macam nilai kategorikal atau menggunakan tipe numerik maka bentuk pohon yang didapatkan biasanya tidak berupa pohon biner.

\section{Teknik pengumpulan data}

Teknik pengumpulan data di penelitian ini untuk mendapatkan sebuah innformasi yang dibutuhkan dalam mencapai sebuah penelitian. Teknik pengumpulan data dalam penelitian ini menggunakan observasi, studi Pustaka, dan wawancara.

1) Observasi

Dalam penelitian ini, peneliti terlibat dengan orang yang sedang diamati atau digunakan sebagai sumber data penelitian (Prof.Dr.Sugiono, 2017). Metode pengumpulan data yang digunakan untuk mengamati lansung, melihat dan mengambil suatu data di sekolah SMPN 38 JAKARTA.

\section{2) Studi Pustaka}

Data dalam penelitian ini kebanyakan diperoleh dari sumber manusia atau human resources, melalui observasi. Metode ini di gunakan untuk mengumpulakan data berupa sejarah singkat sekolah, data-data siswa, sarana dan prasarana sekolah. Teknik ini untuk mendapatkan data yang berkenan dengan judul penelitian ini.

3) Wawancara

Untuk memahami aturan yang perlu ditetapkan dalam mengidentifikasi calon penerima Kartu Indonesia Pintar (KIP), penelitian ini mewawancarai wakil kepala sekolah bidang kesiswaan di SMPN 38 Jakarta.

\section{Tahapan Penelitian}

Dalam penelitian ini analisis data di lakukan dengan tahapan proses Discovery in Databases (KDD), tahapan tersebut dijelaskan sebagai berikut:

\section{1) Data Selection}

Tahapan ini data yang didapat dari SMPN 38 Jakarta adalah data calon penerima KIP (Kartu Indonesia Pintar), dengan jumlah 31 data dan atribut variabel yang ada sebanyak 9 atribut data yang digunakan sebagai berikut:

Tabel 1 keterangan atribut

\begin{tabular}{lcc}
\hline \multicolumn{1}{c}{ Atribut } & \multicolumn{2}{c}{ Detail Penggunan } \\
\hline Nomer Induk & $\checkmark$ & Id \\
Nama Siswa & $\times$ & No \\
Jenis Kelamin & $\checkmark$ & Variabel Bebas \\
Absensi & $\checkmark$ & Variabel Bebas \\
Nilai & $\checkmark$ & Variabel Bebas \\
Tanggungan Orang Tua & $\checkmark$ & Variabel Bebas \\
Bangunan Rumah & $\checkmark$ & Variabel Bebas \\
Penghasilann Orang Tua & $\checkmark$ & Variabel Bebas \\
Diterima & $\checkmark$ & Variabel \\
\hline Sumber: (Yunus, Ramdhan, & &
\end{tabular}

Sumber : (Yunus, Ramdhan, \& Aji, 2021)

tabel diatas menjelaskan mengenai atributatribut yang akan digunakan dalam penelitian, indikator yes $(\checkmark)$ menandakan bahwa atribut bersangkutan akan digunakan dalam penelitian, sedangkan indikator no $(\times)$ menandakan atribut tersebut tidak digunakan pada tahap data mining.

2) Processing (Cleaning)

Dengan 9 atribut predictor dan 1 atribut target dan ada perubahan nama atribut yang bertujuan mempersingkat penyebutannya data terbut di urakan pada tabel dibawah ini:

Tabel 2

Absensi

\begin{tabular}{cc}
\hline $0-2$ hari & Rajin \\
3> hari & Tidak Rajin
\end{tabular}

Sumber : (Yunus et al., 2021) 
Tabel 3

Nilai Rata Rata

\begin{tabular}{cc}
\hline$<60$ & Kurang \\
$60-70$ & Cukup \\
$71-80$ & Baik \\
$>80$ & Sangat Baik \\
\hline
\end{tabular}

Sumber : (Yunus et al., 2021)

Tabel 4

Tanggungan Orang Tua

\begin{tabular}{cl}
\hline 1 & Sedikit \\
$2-3$ & Cukup \\
$>4$ & Banyak \\
\hline
\end{tabular}

Sumber : (Yunus et al., 2021)

Tabel 5

Pendapatan Orang Tua

\begin{tabular}{ll}
\hline$<1.500 .000$ & Sedikit \\
$1.500 .000-2.000 .000$ & Rata - Rata \\
$>2.000 .000$ & Tinggi \\
\hline
\end{tabular}

Sumber : (Yunus et al., 2021)

Dari pengelompokan data yang telah dilakukan, maka atribut-atribut dapat dilihat sebagai berikut:

Tabel 6

Atribut dan Value

\begin{tabular}{cc}
\hline Atribut & Value \\
\hline Absensi & Rajin \\
& Tidak Rajin \\
Nilai & Sangat Baik \\
& Baik \\
Tanggungan Orang Tua & Banyak \\
& Cukup \\
& Sedikit \\
Bangunan Rumah & Sewa \\
& Permanen \\
Pendapatan Orang Tua & Tinggi \\
& Rata-Rata \\
& Rendah \\
\hline
\end{tabular}

Sumber : (Yunus et al., 2021)

\section{3) Transformation}

Dalam tahap ini data tidak ada yang di bersihkan, setelah dilakukan proses tersebut dilakukan pembagian data set dengan menggunakan process split data untuk menghasilkan data training dan data testing dengan rasio 60:40. Data training berjumlah 41 dan data testing berjumlah 31 dari total keseluruhan yaitu 102 data.

4) data Mining

Pada tahap ini, data diproses, diklasifikasikan menurut model, dan kemudian Buat beberapa aturan. Penelitian ini menggunakan algoritma C4.5 menggunakan langkah-langkah dalam algoritma C4.5.

\section{5) Interpretation / Evaluation}

Tahap ini digunakan untuk mengevaluasi empat hasil prediksi yang dihasilkan Algoritma dan metode algoritma yang dipilih Menghasilkan nilai yang mendekati klasifikasi data Sebenarnya.

\section{HASIL DAN PEMBASAN}

Hasil penelitian ini diharapkan untuk menentukan nilai akurasi Algoritma C4.5 dalam penyekleksian calon penerima KIP (Kartu Indonesia Pintar) yang memenuhi kriteria, dengan mengolah data dan memilih atribut yang diperlukan, kemudian menguji data tersebut dengan perhitungan manual dan perangkat lunak Rapidminer. Hasil dari penelitian ini berupa proses perhitungan berdasarkan algoritma C4.5.

1. Pengujian algoritma $\mathrm{C} 4.5$

Pembuatan algoritma C4.5 dilakukan pada kumpulan dataset, dengan data yang sudah di jelasakan sebelumnya pengujian data dapat dihutung dengan beberapa langkah-langkah perhitungan Entrophy dan Gain pada setiap atribut yang dimiliki diterimah yang sebagai variabel target. Dengan menghitung nilai gian disetiap atribut, lalu dengan membandingkan nilai gain tersebut yang nilainya tertinggi akan digunakan sebagai simpul akar atau atribut akar.

2. Pengujian Data Dengan RapidMiner

Pada proses pengujian data yang sudah di import, peneliti menggunakan data training dan data testing untuk menentukan sebuah model decision tree dengan mengunakan perbandingan $60 \%$ untuk data training dan $40 \%$ testing.

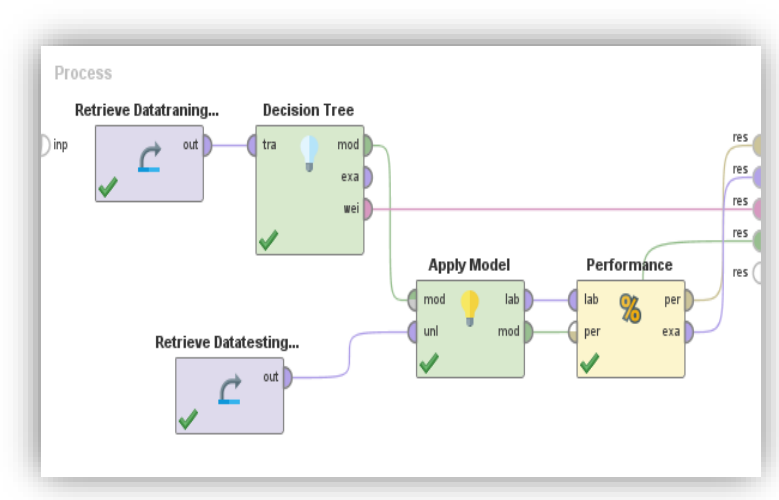

Gambar 1

Proses pengujian data 
3. Hasil Pemodelan Pohon Keputusan

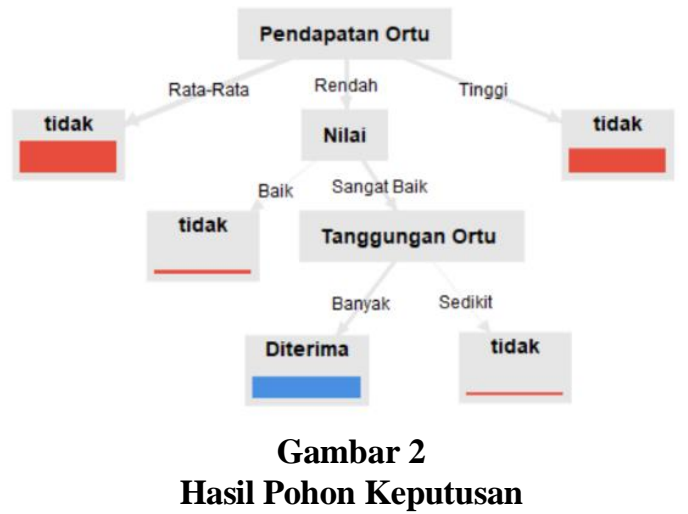

Pohon keputusan C4.5 yang sudah di lihat pada gambar 2 dibaca dari atas ke bawah atau dari akar (simpul pertama paling atas) sampai ke daun (simpul terluar yang tidak lagi memiliki cabang). Berikut cara membacanya dengan mengacu pada tiap simpulnya. Jika Pendapatan Orang Tua rata-rata dan tinggi maka tidak diterima tanpa perlu lagi melihat atribut lainnya. Jika Pendapatan Orang Tua rendah maka terdapat dua kemungkinan, pertama jika Nilai baik maka tidak diterima. Kedua jika Nilai Sangat Baik maka terdapat dua kemungkinan lagi.

Pertama, jika Tanggungan Orang Tua Sedikit maka tidak diterima. Kedua jika Tanggungan Orang tua Banyak maka diterima.

Setelah decision tree atau pohon keputusan sudah dihasilkan, dapat membentuk aturan-aturan seperti gambar 3 dalam permasalahan klasifikasi.

\section{Hasil Accuracy}

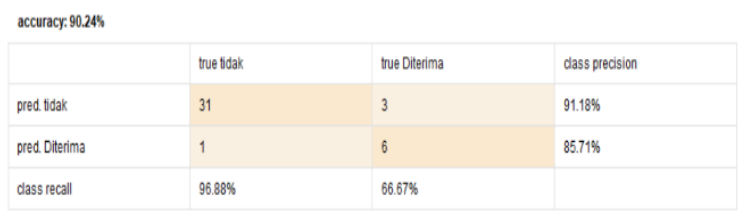

Gambar 3

Hasil Accuracy

Hasil pengukuran hasil accuracy data yang diperoleh dari data training dapat dilihat pada gambar 4 dengan nilai accuracy mencapai 90,24\%. Dari tabel dapat diketahui prediksi data siswa yang diterima dengan true diterima mencapai 6 siswa dan true tidak sebanyak 1 data, dengan hasil nilai presisi sebesar $85,71 \%$. Sedangkan untuk prediksi data siswa yang tidak diterima untuk true diterima mencapai 3 siswa dan true tidak sebanyak 31 siswa, dengan hasil nilai presisi $91.18 \%$. untuk class recall data siswa yang sangat rendah terdapat pada true diterima mencapai $66,67 \%$, sedangkan untuk class recall true tidak mencapai $96,88 \%$.

\section{KESIMPULAN}

Berdasarkan hasil uji coba dan pembahasan yang sudah dilakukan untuk pemilihan penerima Kartu Indonesia Pintar (KIP) di SMPN 38 Jakarta dapat diambil kesimpulan bahwa menggunakan metode klasifikasi dengan algoritma $\mathrm{C} 4.5$ bisa selesaikan. Data siswa dapat diprediksi dengan accuracy yang cukup tinggi, hasil tersebut dapat diperoleh dari data training dan data testing dengan accuracy mencapai $90,24 \%$ sehingga dengan hasil tersebut algoritma C4.5 sangat baik dalam penentuan pemilihan penerima Kartu Indonesia Pintar (KIP).

Dengan hasil accuracy sebesar 90,24\% dapat dijadikan pendukung untuk digunakan oleh pihak SMPN 38 Jakarta dalam pemilihan penerima Kartu Indonesia Pintar (KIP) dengan algoritma C4.5.

\section{REFERENSI}

Adinungroho, S. (2018). Implementasi Data Mining Menggunakan Weka. Malang.

Azahari, N. (2021). Rekomendasi Penerimaan Beasiswa Yayasan Untuk Siswa Baru SMK TI Airlangga dengan Algoritma C4 . 5. 5(April), 609-614. https://doi.org/10.30865/mib.v5i2.2943

Dr. Suyanto. (2017). Data Mining Untuk Klasifikasi Dan Klasterisasi Data. Bandung.

Pauziah, U. (2016). Jurnal String Vol . 1 No . 1 Tahun 2016 ISSN : 2527 - 9661 KAJIAN KOMPARASI ALGORITMA C4 . 5, NAÏVE BAYES DAN NEURAL NETWORK DALAM PEMILIHAN PENERIMA BEASISWA ( Studi Kasus pada SMA Muhammadiyah 4 Jakarta) Pendahuluan Tinjauan Pustaka ISSN : 2527 9661 Metodologi Penelitian Hasil dan Pembahasan. 1(1), 47-56.

Prasetyowati, E. (2017). DATA MINING Pengelompokan Data untuk Informasi dan Evaluasi. Retrieved from https://www.google.co.id/books/edition/DAT A_MINING_Pengelompokan_Data_untuk_Inf $/ \mathrm{rEH} 2 \mathrm{DwAAQBAJ} ? \mathrm{hl}=\mathrm{id} \& \mathrm{gbpv}=0$

Prof.Dr.Sugiono. (2017). METODE PENELITIAN KUANTITATIF, KUALITATIF, DAN R\&D. BANDUNG: ALFABETA.

Sugiyarti, E. (n.d.). SISTEM PENDUKUNG KEPUTUSAN ( DSS ) PENYELEKSIAN PEMILIHAN PENERIMA BEASISWA SMA N 1 ULUBELU TANGGAMUS MENGUNAKAN DATA MINING Eka Sugiyarti , Andino Maseleno Prodi Manajemen informatika STMIK Pringsewu Lampung. File:///C:/Users/Muham/Downloads/Referensi Skripsi/29-176-1-PB.Pdf, 62-69.

Vulandari, R. T. (2017). Data Mining Teori Dan Aplikasi Rapidminer. Yogyakarta. 
Yunus, M., Ramdhan, H., \& Aji, D. R. (2021). PENERAPAN METODE DATA MINING C4.5 UNTUK PEMILIHAN PENERIMA KARTU INDONESIA PINTAR (KIP) PADA SISWA KELASS VIII DI SMPN 38 JAKARTA. JAKARTA. 